\title{
Study of host immunity in patients with Helicobacter pylori-related idiopathic thrombocytopenia
}

S.M. Zahran, ${ }^{7}$ N.A. Hamed, ${ }^{2}$ M. Dafrawy, ${ }^{2}$ H.K. Abdelaziz ${ }^{3}$ and M.G. Morsi ${ }^{4}$

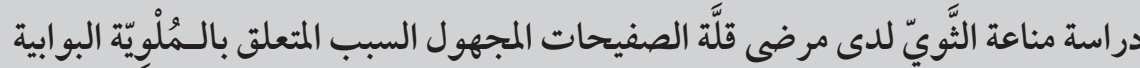

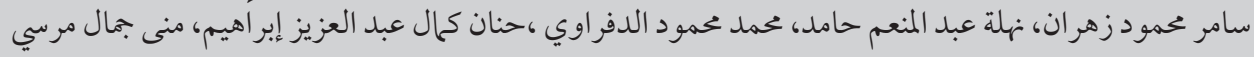

الخلاصـة: أجرى الباحثون هذه الدراسة لاختبار دور الخلايا التائية المساعدة Th1 في المناعة، وقد شملت الدراسة 24 مريضاً بقلة الصفيحات المجهولة

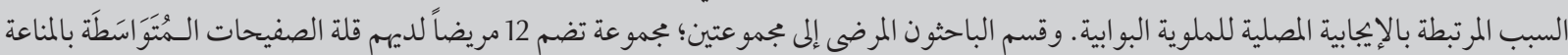

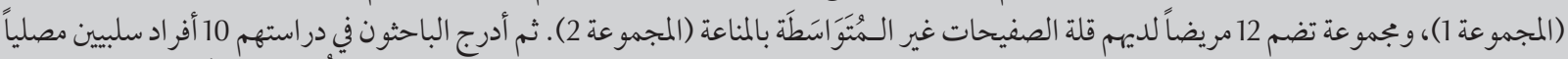

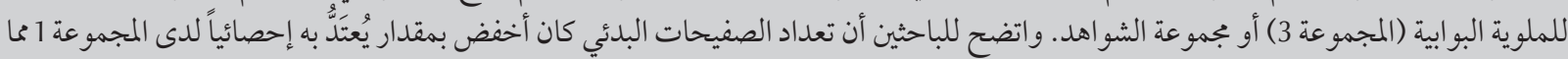

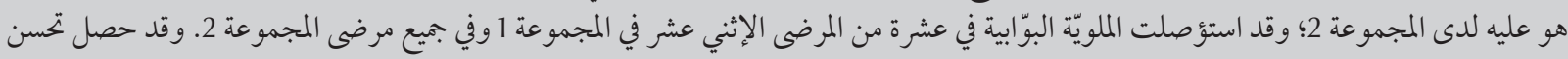

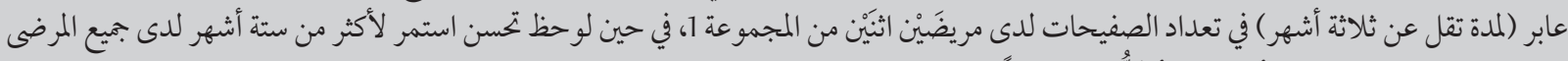

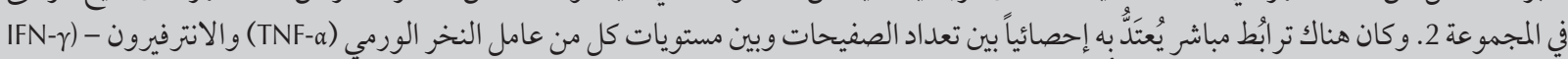

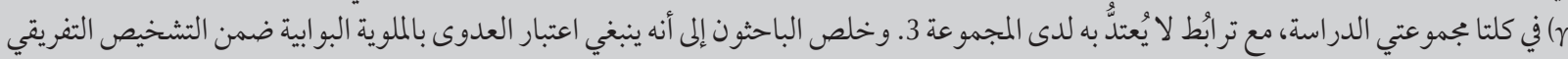

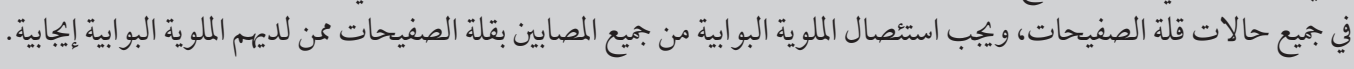

ABSTRACT To test the role of T helper cell Th1 immunity we recruited 24 patients with idiopathic thrombocytopenia associated with $H$. pylori seropositivity. They were divided into 2 groups: 12 with immunemediated thrombocytopenia (Group 1) and 12 with non-immune mediated thrombocytopenia (Group 2). We also recruited 10 individuals seronegative for H. pylori (Group 3) as controls. Initial platelet count was significantly lower in Group 1 than Group 2. H. pylori was eradicated in 10 of 12 patients in Group 1 and in all patients in Group 2. Transient improvement ( $<3$ months) in the platelet count occurred in only 2 patients in Group 1 while improvement for $>6$ months was observed in all patients in Group 2. There was a statistically significant direct correlation between platelet count and levels of TNF- and IFN- $\gamma$ in both study groups, while a non-significant correlation was seen in Group 3. Thus, H. pylori infection should be considered in the differential diagnosis of all cases of thrombocytopenia, and should be eradicated in all $H$. pylori-positive patients with thrombocytopenia.

Étude de l'immunité de l'hôte chez des patients atteints d'une thrombocytopénie idiopathique liée à Helicobacter pylori

RÉSUMÉ Afin de tester le rôle de l'immunité des lymphocytes T auxiliaires de type Th1, nous avons recruté 24 patients atteints de thrombocytopénie idiopathique associée à une séropositivité pour Helicobacter pylori. Ils ont été répartis en deux groupes : 12 patients souffrant d'une thrombocytopénie à médiation immunitaire (groupe 1) et 12 patients atteints d'une thrombocytopénie à médiation non immunitaire (groupe 2). Nous avons aussi recruté 10 personnes séronégatives pour H. pylori (groupe 3) comme témoins. La numération plaquettaire initiale était nettement plus faible dans le groupe 1 que dans le groupe 2. H. pylori a été éradiqué chez 10 patients sur 12 dans le groupe 1 et chez tous les patients du groupe 2. Une amélioration transitoire ( $<3$ mois) de la numération plaquettaire a été observée chez seulement deux patients du groupe 1 tandis qu'une amélioration de plus de six mois a été enregistrée chez tous les patients du groupe 2. Une corrélation directe statistiquement significative a été constatée entre la numération plaquettaire et les taux de TNF- $\alpha$ et d'IFN- $\gamma$ dans les deux groupes étudiés, alors qu'une corrélation non significative a été observée dans le groupe 3. Par conséquent, l'infection à H. pylori doit être envisagée dans le diagnostic différentiel pour tous les cas de thrombocytopénie et doit être éradiquée chez tous les patients atteints de thrombocytopénie positifs pour $H$. pylori.

${ }^{1}$ Department of Biochemistry, Faculty of Pharmacy, Pharos University, Alexandria, Egypt. ${ }^{2}$ Haematology Unit, Department of Internal Medicine; ${ }^{3}$ Department of Medical Biochemistry; ${ }^{4}$ Department of Microbiology \& Immunology, Faculty of Medicine, Alexandria University, Alexandria, Egypt (Correspondence to H.K. Abdelaziz: hanankam83@yahoo.com).

Received: 26/02/12; accepted: 09/05/12 


\section{Introduction}

Helicobacter pylori is a Gram-negative bacterium that colonizes the mucous layer of the human stomach [1]. It causes gastritis and is an important risk factor for gastric ulcer, duodenal ulcer, gastric cancer and gastric mucosa-associated lymphoid tissue lymphoma. In addition to its role in gastroduodenal diseases, H. pylori infection has been associated with a number of non-digestive system diseases including chronic thyroiditis, rheumatoid arthritis, Sjögren syndrome and immune thrombocytopenic purpura (ITP) [1].

According to the Maastricht III consensus conference, ITP along with unexplained iron deficiency anaemia are extra-intestinal diseases for which $H$. pylori infection detection and eradication are indicated [2]. The role of H. pylori in the pathogenesis of ITP is still controversial. Several mechanisms have been proposed to explain the association. The first is molecular mimicry, i.e. the presence of cross reaction between antibodies against the cytotoxinassociated gene (CagA) of H. pylori, and platelet antigens causing accelerated platelet clearance [3]. Another proposed mechanism is modulation of host immunity following colonization by $H$. pylori to favour the emergence of autoreactive B-1 cells and the enhancement of phagocytic capacity of monocytes together with low levels of the inhibitory $\mathrm{F} c \gamma$ receptor IIB [4].

The aim of this work was to test the role of T helper cell Th1 immunity by correlating tumour necrosis factor alpha and gamma interferon (Th1 cytokines) to platelet count in $H$. pyloriinfected idiopathic thrombocytopenic patients. Adding H. pylori eradication therapy to standard therapy for thrombocytopenia may result in better response.

\section{Methods}

The study was carried out on 24 randomly selected patients ( 17 females and 7 males) seropositive for $H$. pylori, who had chronic ITP and had presented to Alexandria Main University Hospital during the period March-December 2010. The age range of the patients was 14-34 [mean 24.83; standard deviation (SD) 5.26] years. They presented with purpura or bleeding from different sites but without dyspeptic symptoms (nausea, vomiting, epigastric pain). Patients with hepatic, pulmonary, renal, cardiac diseases, overt autoimmune disease, malignancy, human immunodeficiency virus (HIV) infection, and hepatitis C virus infection as well as those who had previously undergone $H$. pylori eradication therapy were excluded from the study.

Informed, written consent was obtained from all participants or a parentfor those who were under the age of consent. The study was approved by the ethics committee of Alexandria University.

According to the aetiology of thrombocytopenia, the 24 participants were divided into 2 main groups. Group 1 consisted of 12 patients with immune thrombocytopenia [9 newly diagnosed, 3 refractory to steroid, i.e. patients with persistent symptomatic and severe thrombocytopenia $<10000 / \mu \mathrm{L}$ after 2 weeks of prednisone $(1 \mathrm{mg} / \mathrm{kg} /$ day)]. Group 2 consisted of 12 newly diagnosed patients with non-immune thrombocytopenia. Splenectomy had not been performed in any patient in Group 1 at presentation. We also recruited 10 healthy persons from among the relatives of the patients (Group 3, control group). These were matched for age and sex and they were all seronegative for H. pylori.

ITP was defined as isolated thrombocytopenia with no clinically apparent associated conditions or other causes of thrombocytopenia according to the American Society of
Hematology guidelines [5]. H. pylori eradication therapy regimen consisted of amoxicillin (1000 mg twice daily), clarithromycin (500 mg twice daily) and omeprazole (20 mg twice daily) for 1 week. To assess the response to eradication therapy, the $H$. pylori antigen stool test was repeated 4 weeks after the completion of eradication therapy.

The platelet count was determined in each participant in Groups 1 and 2 immediately before eradication therapy was initiated, and counts were monitored for at least 6 months after completion of eradication therapy, being measured every 4 weeks. Those who did not attend on a regular basis were excluded from the study. Response to treatment was defined as complete if the platelet count was above $150 \times$ $10^{9} / \mathrm{L}$, and partial if the platelet count increased by more than $50 \times 10^{9} / \mathrm{L} 6$ months after the eradication therapy [6].

All participants in this study were subjected to:

- thorough history-taking and clinical examination with special stress on duration of ITP before eradication treatment, previous and concomitant treatment for ITP and history of any eradication regimen administered;

- complete blood picture;

- bone marrow aspiration (for patients only) to exclude secondary causes for thrombocytopenia;

- hepatic and renal function tests;

- serum enzyme-linked immunosorbent assay (ELISA) testing for H. pylori $\operatorname{IgG}[7]$;

- stool antigen assay (HpSA) [8];

- antiplatelet platelet antibody detection (for patients only) by modified antigen-capture enzyme immunoassay (MACE):Antibodies against platelet glycoprotein (GP) GPIb/IX, GPIIb/IIIa, and other platelet antigens were detected using monoclonal antibody-specific immobilization of platelet antigens (MAIPA) [9]; 
- quantitative measurement of serum tumour necrosis factor alpha (TNF- $\alpha)$ and gamma interferon (IFN- $\gamma$ ) using the ELISA kit (RayBio, United States of America) [10,11]. A 5-mL sample of blood was collected for the detection of H. pylori antibodies just before the endoscopy. The samples were kept at room temperature for 1 hour, followed by centrifugation at $1500 \mathrm{rpm}$ for $10 \mathrm{~min}$. The serum was aliquoted into cryovials and stored at $-70^{\circ} \mathrm{C}$.

Serum samples were tested for the presence of anti- $H$. pylori antibodies using EIAgen H. pylori IgG kit (Adaltis, Italy). This is based on a "sandwich "enzyme immunoassay, where samples and standards were incubated in microtitre plate wells coated with the first monoclonal anti-IgG antibody in the presence of a second anti-IgG monoclonal antibody linked to acetylcholinesterase (assay range: 5-1000 pg). All steps were carried out according to the manufacturer's instructions.

A stool sample was collected within 3 days of the endoscopy and before the initiation of any therapy against $H$. pylori. Samples were stored in a coolbox containing ice packs until they were transferred to the laboratory, where they were immediately transferred to cryovials and stored at $-70^{\circ} \mathrm{C}$ until tested.

Diluted stool samples were analysed using the HpSA enzyme immunoassay kit according to the manufacturer's instructions (Meridian Diagnostics, Inc., Cincinnati). The kit employs affinity-purified polyclonal anti-H. pylori rabbit antibodies adsorbed to microwell plates. Following addition of peroxidase-coupled antibody and substrate, the colour reaction was read using quantitative spectrophotometric determination (450 nm). HpSA optical density values above 0.160 were considered positive; values between 0.140 and 0.159 indeterminate, and values below 0.140 negative.

Antibodies against platelet glycoprotein GPIb/IX, GPIIb/IIIa, and other platelet antigens were detected using monoclonal antibody-specific immobilization of platelet antigens (MAIPA), a novel antigen-specific capture assay for the detection of platelet antibodies (Geissen, Berlin,Germany).

Statistical analysis was done using SPSS, version 9.0.0. Results are expressed as mean and standard deviation. Chi-squared was used for analysis of categorical data. Analysis of variance (ANOVA) test was done for comparison of means of quantitative data between the 3 groups. Further analysis of the ANOVA test was done using least significant differences (LSD) to determine the difference between means. Pearson's correlation $(r)$ was used to study the correlation between initial platelet count and different variables. $P$ value $<0.05$ was considered statistically significant.

\section{Results}

Table 1 shows the age and sex of the 3 groups: age ranged from 14 to 34 years (mean 24.83; SD 5.26). There was no statistically significant age or sex difference between the control and patient groups.
There were statistically significant differences between the 3 groups as regards initial platelet count, TNF- $\alpha$ and IFN- $\gamma$ (Table 2). Initial platelet count was lower in the immune mediated (Group 1) than in the non-immune mediated (Group 2) H. pylori-seropositive patients. H. pylori was eradicated in 10 of 12 treated patients in group 1 and in all 12 patients in group 2. Transient improvement (<3 months) in the platelet count occurred in only 2 patients in Group 1 while improvement of more than 6 months was observed in all patients in Group 2 (Table 2). Platelet recovery was observed as early as 1 week after $H$. pylori eradication in 4 patients, and 2 weeks after completion of eradication therapy in the rest of the Group 2 patients.

Table 3 shows the correlation between initial platelet count and age, TNF- $\alpha$ and IFN- $\gamma$ levels. There was highly significant direct correlation between platelet count and levels of TNF- $\alpha(r=0.829, P=0.001)$ and IFN- $\gamma$ $(r=0.812, P=0.001)$ in Group 1, and a statistically significant direct correlation between initial platelet count and levels of TNF- $\alpha(r=0.698, P=0.012)$ and $\operatorname{IFN}-\gamma(r=0.579, P=0.049)$ in Group 2. In Group 3, however, there was no statistically significant correlation between initial platelet count and TNF- $\alpha$ or IFN- $\gamma$ levels.

\section{Discussion}

No dyspeptic symptoms were present in any patient of both groups. A significant association between $H$. pylori

\begin{tabular}{|c|c|c|c|c|}
\hline Parameter & $\begin{array}{c}\text { Group } 1 \\
(n=12)\end{array}$ & $\begin{array}{c}\text { Group } 2 \\
(n=12)\end{array}$ & $\begin{array}{c}\text { Group } 3 \\
(n=10)\end{array}$ & Statistics \\
\hline Age (years), [mean (SD)] & $25.41(7.29)$ & $24.25(2.01)$ & $25.2(6.3)$ & $F=0.143 ; P=0.867$ \\
\hline Males & 4 & 3 & 4 & \multirow{2}{*}{$\chi^{2}=0.569 ; P=0.752$} \\
\hline Females & 8 & 9 & 6 & \\
\hline
\end{tabular}

Group 1 = patients with immune thrombocytopenia; Group 2 = patients with non-immune thrombocytopenia; Group 3 = controls.

$S D=$ standard deviation. 


\begin{tabular}{|c|c|c|c|c|}
\hline Parameter & $\begin{array}{l}\text { Group } 1 \\
(n=12)\end{array}$ & $\begin{array}{c}\text { Group } 2 \\
(n=12)\end{array}$ & $\begin{array}{l}\text { Group } 3 \\
(n=10)\end{array}$ & Statistics \\
\hline $\begin{array}{l}\text { Initial platelet count }(\times 109 / L)[\text { mean } \\
(S D)]\end{array}$ & $16.9(5.3)$ & $82.7(13.8)$ & $325.6(60.7)$ & $\begin{array}{l}\mathrm{F}=245.168 ; \mathrm{P}<0.001 ; \\
\mathrm{LSD}:(1,2)^{*},(1,3)^{*},(2,3)^{*}\end{array}$ \\
\hline Platelet specific antibodies & Present & Absent & Absent & \\
\hline Helicobacter pylori eradication & 10 patients & 12 patients & - & \\
\hline No. of responders & 2 patients & 12 patients & - & \\
\hline Time to response (weeks) & 4 & $\begin{array}{l}1 \text { (4 patients); } \\
2 \text { (8 patients) }\end{array}$ & - & \\
\hline Duration of response (months) & $<3$ & $>6$ & - & \\
\hline TNF- $\alpha(p g / m L)[$ mean (SD)] & $60.3(18.1)$ & $49.7(8.5)$ & $31.9(28.6)$ & $\begin{array}{l}\mathrm{F}=14.873 ; \mathrm{P}<0.001 \\
\text { LSD: }(1,2)^{*},(1,3)^{*},(2,3)^{*}\end{array}$ \\
\hline IFN- $\gamma(p g / m L)$ [mean (SD)] & $69.9(17.5)$ & $53.8(21.1)$ & $36.9(4.7)$ & $\begin{array}{l}\mathrm{F}=8.962 ; \mathrm{P}<0.001 \\
\text { LSD: }(1,2)^{*},(1,3)^{*},(2,3)^{*}\end{array}$ \\
\hline
\end{tabular}

Group $1=$ patients with immune thrombocytopenia; Group 2 = patients with non-immune thrombocytopenia; Group $3=$ controls. $F=$ analysis of variance test, $L S D=$ least significant difference,

$S D=$ standard deviation; $T N F=$ tumour necrosis factor; IFN = interferon.

infection and the presence of dyspepsia has been reported by some researchers [12] but not by others [13].

Initial platelet count was lower in the immune mediated (Group 1) than in the non-immune mediated (Group 2) patients. Although H. pylori was eradicated in 10 of 12 treated patients in group 1 and in all patients in Group 2 , transient improvement ( $<3$ months) in the platelet count occurred in only 2 patients in Group 1 while improvement over more than 6 months was observed in all patients in Group 2. The pretreatment factor that was more consistently associated with a platelet response to $H$. pylori eradication was a shorter ITP duration [6]. There are conflicting reports about the predictive value of age and baseline platelet count. The variability of H. pylori strains may be a contributing factor $[14,15]$.

Platelet recovery was observed as early as 1 week after $H$. pylori eradication in 4 patients, and 2 weeks after completion of eradication therapy in the rest of the Group 2 patients. The observed low number of patients with platelet recovery in Group 1 may be attributed to initial low platelet count. Many study designs consider the first assessment of the platelet count 1 month after eradication therapy [16]. However, platelet recovery was observed as early as 3 days after eradication in one report [17] and in another there was a rapid platelet increase within 1 week in roughly half of the responders [18]. Responses have also been observed several weeks after eradication [16]. The minimum duration of the platelet increase that defined a response was 1 month in one study [19] and 3 months in 2 other studies [20,21].

The improvement in platelet count following $H$. pylori eradication has been explained by 1) clarithromycin included in eradication regimens has anti-inflammatory properties which may improve platelet autoreactivity by blocking the production of proinflammatory cytokines, and 2) antimicrobials used for H. pylori treatment may eradicate other commensal bacteria that stimulate cross reactive platelet antibodies [4]. In support of these hypotheses, a 2009 meta-analysis showed an increase in platelet count following treatment in some patients with ITP regardless of the outcome of eradication therapy [4].

The increased platelet count in patients in whom H. pylori eradication failed or in those who received proton pump inhibitor monotherapy could be mediated through a reduction in the quantity of H. pylori and/or a bacteriostatic effect of the regimen [6].
In our study IFN- $\gamma$ and TNF- $\alpha$ levels were significantly higher in the study groups compared with the control. $H$. pylori infection and ITP are associated with a T helper 1 (Th1)-type immune response [6] characterized by increased levels of Th1 cytokines, such as IFN- $\gamma$ and TNF- $\alpha$, which can increase the release of proinflammatory cytokines [22]. Overproduction of TNF- $a$ can lead to autoimmune disease. Hence, $H$. pylori-induced alterations in cytokine profiles might promote development of immune thrombocytopenia [23].

In Group 1, there was highly significant direct correlation between platelet count and levels of TNF- $\alpha$ and IFN- $\gamma$; in Group 2 a statistically significant direct correlation was present between initial platelet counts and levels of TNF- $\alpha$ and IFN- $\gamma$. In Group 3, no statistically significant correlation was observed. IFN- $\gamma$ and TNF- $\alpha$ affect B-cell proliferation and differentiation into immunoglobulin secreting cells. In addition, IFN- $\gamma$ and TNF- $\alpha$ also enhance the function of macrophages, upregulating the expression of their IgG receptors. Abnormalities in the production of these cytokines may be involved in the clinical course of autoimmune thrombocytopenic purpura [24]. The absence of platelet-specific antibodies 


\begin{tabular}{|c|c|c|c|c|}
\hline Parameter & Age (years) & $\begin{array}{l}\text { Platelet count } \\
\qquad\left(\times 10^{9} / \mathrm{L}\right)\end{array}$ & $\begin{array}{l}\text { TNF- } \alpha \\
(\mathrm{pg} / \mathrm{mL})\end{array}$ & $\begin{array}{c}\text { IFN- } \gamma \\
(\mathrm{pg} / \mathrm{mL})\end{array}$ \\
\hline \multicolumn{5}{|c|}{ Group 1} \\
\hline \multicolumn{5}{|l|}{ Age (years) } \\
\hline$r$ & & 0.23 & 0.30 & 0.19 \\
\hline$P$ & & 0.47 & 0.34 & 0.548 \\
\hline \multicolumn{5}{|c|}{ Platelet count $\left(\times 10^{9} / \mathrm{L}\right)$} \\
\hline$r$ & 0.23 & & 0.829 & 0.81 \\
\hline$P$ & 0.47 & & 0.001 & $0.001^{*}$ \\
\hline \multicolumn{5}{|c|}{$T N F-a(p g / m L)$} \\
\hline$r$ & 0.30 & 0.829 & & 0.797 \\
\hline$P$ & 0.34 & $0.001^{*}$ & & $0.002^{*}$ \\
\hline \multicolumn{5}{|c|}{$I F N-\gamma(p g / m L)$} \\
\hline$r$ & 0.19 & 0.81 & 0.797 & \\
\hline$P$ & 0.548 & $0.001^{*}$ & $0.002^{*}$ & \\
\hline \multicolumn{5}{|c|}{ Group 2} \\
\hline \multicolumn{5}{|l|}{ Age (years) } \\
\hline$r$ & - & -0.395 & -0.329 & 0.059 \\
\hline$P$ & - & 0.204 & NS & NS \\
\hline \multicolumn{5}{|c|}{ Platelet count $\left(\times 10^{9} / \mathrm{L}\right)$} \\
\hline$r$ & -0.395 & - & $0.698^{*}$ & $0.579^{*}$ \\
\hline$P$ & 0.204 & - & 0.012 & 0.049 \\
\hline \multicolumn{5}{|c|}{$T N F-\alpha(p g / m L)$} \\
\hline$r$ & -0.329 & $0.698^{*}$ & - & 0.432 \\
\hline$P$ & 0.296 & 0.012 & - & 0.161 \\
\hline \multicolumn{5}{|c|}{$I F N-\gamma(p g / m L)$} \\
\hline$r$ & 0.059 & $0.579^{*}$ & 0.432 & - \\
\hline$P$ & 0.856 & 0.049 & 0.161 & - \\
\hline \multicolumn{5}{|c|}{ Group 3} \\
\hline \multicolumn{5}{|l|}{ Age (years) } \\
\hline$r$ & & -0.27 & -0.15 & 0.14 \\
\hline$P$ & & 0.448 & 0.678 & 0.69 \\
\hline \multicolumn{5}{|c|}{ Platelet count $\left(\times 10^{9} / \mathrm{L}\right)$} \\
\hline$r$ & -0.27 & & 0.507 & 0.42 \\
\hline$P$ & 0.448 & & 0.135 & 0.227 \\
\hline \multicolumn{5}{|c|}{$T N F_{-\alpha}(p g / m L)$} \\
\hline$r$ & -0.15 & 0.507 & & -0.186 \\
\hline$P$ & 0.678 & 0.135 & & 0.606 \\
\hline \multicolumn{5}{|c|}{$I F N-\gamma(p g / m L)$} \\
\hline$r$ & 0.14 & 0.42 & -0.186 & \\
\hline$P$ & 0.69 & 0.227 & 0.606 & \\
\hline
\end{tabular}

${ }^{*}$ Correlation is significant at the 0.05 level (2-tailed).

$T N F=$ tumour necrosis factor; I I N = interferon; $r=$ Pearson correlation

$N S=$ not significant $(P \geq 0.05)$.

in Group 2 may be explained by the requirement for a certain level of Th1 cytokines to elicit antibody production or perhaps the antibody titre is below the limit of detection. Further studies are needed to confirm this possibility because of the low number of patients in our study.
T-cells are generally hyporesponsive during $H$. pylori infection, and the response is polarized toward a $\mathrm{T}$ helper 1 (Th1) response. This type of response 
may be induced by $H$. pylori neutrophilactivating protein and the cell wall lipopolysaccharide [6].

\section{Conclusion}

Despite the low number of the studied patients, we can suggest that even in the absence of antibodies against platelets, an immune process is still present; thus H. pylori infection should be considered in the differential diagnosis of all cases of thrombocytopenia (immune and non-immune) and should be routinely included in the initial work up of chronic thrombocytopenia. We also suggest that $H$ .pylori should be eradicated in all $H$. pylori-positive patients with thrombocytopenia. However, this research need to be repeated on a wider scale to confirm this finding.

Funding: This study did not receive any funding.

Competing interests: None declared.

\section{References}

1. Kurtoglu El, Kayacetin E, Ugur A. Helicobacter pylori infection in patients with autoimmune thrombocytopenic purpura. World Journal of Gastroenterology, 2004, 10(14):2113-2115.

2. Stasi R et al. Effects of eradication of Helicobacter pylori infection in patients with immune thrombocytopenic purpura: a systematic review. Blood, 2009, 113:1231-1240.

3. Franchini M, Veneri D. Helicobacter pylori infection and immune thrombocytopenic purpura. Haematologica, 2003, 88:1087-1091.

4. Arnold DM et al. Platelet count response to H. pylori treatment in patients with immune thrombocytopenic purpura with and without H. pylori infection: a systematic review. Haematologica, 2009, 94:850-856.

5. George JN et al. Idiopathic thrombocytopenic purpura: a practice guideline developed by explicit methods for the American Society of Hematology. Blood, 1996, 88:3-40.

6. Stasi R, Provan D. Helicobacter pylori and chronic ITP. Hematology/the Education Program of the American Society of Hematology, 2008, 2008:206-211.

7. Andrews J et al. Comparison of three stool antigen tests for Helicobacter pylori detection. Journal of Clinical Pathology, 2003, 56:769-771.

8. McNulty $\mathrm{C}$ et al. Test and treat for dyspepsia-but which test? BMJ (Clinical Research Ed.), 2005, 330:105-106.

9. Kim $\mathrm{H}$ et al. [Detection of platelet specific antibodies by modified antigen capture ELISA test.]. Korean Journal of Laboratory Medicine, 2006, 26:192-197. [in Korean].

10. Schroder K et al. Interferon- $\gamma$ : an overview of signals, mechanisms and functions. Journal of Leukocyte Biology, 2004, 75:163-189.

11. Bayraktaroğlu T et al. Serum levels of tumor necrosis factor- $\alpha$, interleukin-6 and interleukin-8 are not increased in dyspeptic patients with Helicobacter pylori-associated gastritis. Mediators of Inflammation, 2004, 13:25-28.

12. Michel $\mathrm{M}$ et al. Does Helicobater pylori initiate or perpetuate immune thrombocytopenic purpura? Blood, 2004, 103:890896.

13. Stasi R et al. Helicobacter pylori eradication in the management of patients with idiopathic thrombocytopenic purpura. American Journal of Medicine, 2005, 118:414-419.
14. Takahashi T, Yujiri T, Tanizawa Y. Helicobacter pylori and chronic ITP: the discrepancy in the clinical responses to eradication therapy might be due to differences in the bacterial strains. Blood, 2004, 104:594.

15. Veneri D et al. Idiopathic thrombocytopenic purpura, Helicobacter pylori infection, and HLA class II alleles. Blood, 2002, 100:1925-1926.

16. Asahi A et al. Effects of a Helicobacter pylori eradication regimen on anti-platelet autoantibody response in infected and uninfected patients with idiopathic thrombocytopenic purpura. Haematologica, 2006, 91:1436-1437.

17. Hino $\mathrm{M}$ et al. Platelet recovery after eradication of Helicobacter pylori in patients with idiopathic thrombocytopenic purpura. Annals of Hematology, 2003, 82:30-32.

18. Franchini $\mathrm{M}$ et al. Effect of Helicobacter pylori eradication on platelet count in idiopathic thrombocytopenic purpura: a systematic review and meta-analysis. Journal of Antimicrobial Chemotherapy, 2007, 60:237-24.

19. Ando $\mathrm{K}$ et al. Can eradication therapy for Helicobacter pylori really improve the thrombocytopenia in idiopathic thrombocytopenic purpura? Our experience and a literature review. International Journal of Hematology, 2003, 77:239-244.

20. Emilia G et al. Helicobacter pylori infection and chronic immune thrombocytopenic purpura: long-term results of bacterium eradication and association with bacterium virulence profiles. Blood, 2007, 110:3833-3841.

21. Ahn ER et al. Platelet activation in Helicobacter pylori-associated idiopathic thrombocytopenic purpura: eradication reduces platelet activation but seldom improves platelet counts. Acta Haematologica, 2006, 116:19-24.

22. Wu Y-Y et al. Helicobacter pylori enhances tumor necrosis factor-related apoptosis-inducing ligand-mediated apoptosis in human gastric epithelial cells. World Journal of Gastroenterology, 2004, 10:2334-2339.

23. McCrae KR. Helicobacter pylori and ITP: many questions, few answers. Blood, 2004, 103:752-753.

24. Garcia-Suarez $\mathrm{J}$ et al. Abnormal $\gamma$ IFN and $\gamma$ TNF secretion in purified CD2+ cells from autoimmune thrombocytopenic purpura (ATP) patients: their implication in the clinical course of the disease. American Journal of Hematology, 1995, 49:271-276. 